\title{
THE EMERGENCE OF INTERNATIONAL INVESTMENT LAW: FROM STATE CONTRACTS TO BILATERAL INVESTMENT TREATIES
}

A. PROTECTING FOREIGNERS' RIGHTS THROUGH TRADITIONAL RULES AND MECHANISMS

1. Diplomatic protection

(a) Diplomatic protection as a protection for investors

(i) A brief description of the mechanism

1.004

1.005

(ii) Conditions for the exercise of diplomatic protection $\quad 1.009$

(b) The weaknesses of diplomatic protection for the purposes of foreign investors' protection

1.015

2. On Mixed Commissions and the protection of foreign economic operators

(a) The origin and development of Mixed Commissions

(b) The legacy of the Mixed Commissions

3. The development of arbitration

(a) Resorting to arbitration

(b) The evolution of arbitration

(i) The Permanent Court of Arbitration

(ii) The institutional development of arbitration since 1945

B. THE EMERGENCE OF STATE CONTRACTS

1. Appearance and development of State contracts (a) The existence of contracts between foreign private persons and States

(b) The application of international law and the emergence of State contracts

(i) The issue of determining the applicable law

(ii) The internationalization of State contracts through contractual practices

(iii) The internationalization of State contracts through arbitral practice

2. Identifying which international law norms are applicable to State contracts: a general overview

C. BILATERAL INVESTMENT TREATIES AND THE BIRTH AND RISE OF INTERNATIONAL INVESTMENT LAW

1. The emergence and development of investment protection treaties $\quad 1.084$

2. The AAPL Award and the emergence of contemporary investment law 1.092

(a) A new consent to arbitration 1.093

(b) The development of international investment law since 1990

An international law matter. International investment law did not appear from nowhere. It would make sense to assume that it emerged in 1990 along with the AAPL $v$ Sri Lanka ruling, ${ }^{1}$ but as is often the case, reality is much 
more subtle. International investment law did not develop ex nibilo, as its roots are almost as ancient as those of general international law. In a nutshell, we could say that international investment law is the application, in a particular economic sector, of rules and legal mechanisms that have been in place for a long time.

1.002 Old questions, new rules. The needs that justified the development of international investment law are far from being new. The protection of individuals provided by States has always been a major issue for international relationships in the Westphalian world. One can recall that E. de Vattel wrote in the 18th century that a State cannot welcome foreigners 'to trap them'. $\mathrm{He}$ went on by considering that 'as soon as the State receives them, it commits itself to protect them as if they were its own nationals and to provide them full security to the greatest extent possible'. ${ }^{2}$ The mere principle of a protection granted to foreigners was established quite quickly, at a time when international law as we understand it today simply did not exist. Yet, the first attempts aiming at the protection of goods and assets of foreigners appeared later, through the establishment of mechanisms that can be considered as the source of the contemporary system (A). In the meantime, the increased use of a new legal instrument - later called 'State contract' - widely contributed to an internationalization of the legal relationship between host States and foreign investors (B). However, international investment law as we know it today truly appeared with the growth of investment protection treaties (C).

\section{A. PROTECTING FOREIGNERS' RIGHTS THROUGH TRADITIONAL RULES AND MECHANISMS}

1.003 Concrete example. Let us imagine that, during the second half of the 19th century, a French businessman tries to make a fortune in a faraway country let us say in Latin America. Everything goes well at first, the country is young and in need of capital and the know-how that has been developed in Europe for some decades. But let us imagine then that after a few years, the government of this country is overthrown and all the goods possessed by the businessman are confiscated: the mine is closed, the building site is interrupted, the project is given up, etc. What solution can we offer him? The first and most obvious one would be to file a claim before the national judges. But

2 Our translation of the French original: E. de Vattel, Le droit des gens ou principes de la loi naturelle appliquée à la conduite et aux affaires des nations et des souverains, 1758, Tome 1, Paris, Rey \& Gravier, 1820, Book II, Chapter 8, para. 104: 'Dès qu'il les reçoit, il s'engage à les protéger comme ses propres sujets, à les faire jouir, autant qu'il dépend de lui, d'une entière sûreté'. 
there are several reasons why, in most cases, it would not be efficient. As said before, the country is young as it obtained its independence only recently. In most cases, a recent independence implies a certain weakness of the State's institutions (and the recent overthrowing of the government is an illustration of it). Therefore, a claim before a national judge is quite likely to fail. Such a situation, which could amount to a denial of justice under certain circumstances, led foreign investors to seek protection under international law. Three well-known options existed back then. They brought so much to international investment law that they are worth mentioning here. These options are: diplomatic protection, Mixed commissions, and international arbitration.

\section{Diplomatic protection}

General principle. Diplomatic protection is a long-standing institution in 1.004 international law. It has nonetheless been convincingly argued that it does not provide sufficient protection for foreign investors. Nowadays, economic operators usually seek protection under other types of mechanisms, which is how international investment law came to be. ${ }^{3}$ We will mention here the main aspects of this evolution. ${ }^{4}$

\section{(a) Diplomatic protection as a protection for investors}

\section{(i) A brief description of the mechanism}

Diplomatic protection today. We cannot help but notice that diplomatic protection has experienced a certain decline. Yet, the International Court of Justice (ICJ) has recently heard cases related to this mechanism, in particular the LaGrand ${ }^{5}$ and the Avena ${ }^{6}$ cases, or more recently the Diallo ${ }^{7}$ case. Even if those cases did not involve only diplomatic protection requests, it still shows us that this institution remains relevant in contemporary international disputes.

The mechanism of diplomatic protection. Regardless of recent evolutions, diplomatic protection seems to be perfectly suited to ensure the protection of foreign investors. Indeed, diplomatic protection aims at protecting an individual against the acts of a State he or she is not a national of - these acts

3 See: Charles Leben, 'La théorie du contrat d'Etat et l'évolution du droit international des investissements', The Hague Academy of International Law, Recueil des cours - Collected courses, vol. 302, 2003(I), pp. 197-386.

4 On the evolution of diplomatic protection for the purpose of protecting foreign investment, see also B. Stern, 'La protection diplomatique des investissements internationaux. De la Barcelona Traction à Sicula ou les glissements progressifs de l'analyse', 1990 J.D.I. (Clunet) 881-931.

5 Germany v. United States, 27 June 2001, ICJ Rep., p. 466.

6 Mexico v. United States, 31 March 2004, ICJ Rep. p. 12.

7 Republic of Guinea v. Democratic Republic of Congo, decision on the merits 30 November 2010, ICJ Rep. p. 639. 
being, for instance, imprisonment of the individual for no legitimate reason, conducting a hasty trial, confiscating his or her goods, prohibiting the exercise of an activity, etc. In such circumstances, the State of which the individual is a national may act on his or her behalf and make a claim against the State that committed the acts. The conflict then becomes a dispute between two States: the Permanent Court of International Justice (PCIJ) indeed considered in a very famous statement that the State acting for the diplomatic protection of its national is asserting its own rights by claiming (...) an indemnity on the ground that M. Mavrommatis, one of its subjects, has been treated by the Palestine or British authorities in a manner incompatible with certain international obligations which they were bound to observe'. ${ }^{8}$ In such a case, the State is not acting in the name of its national: this action is not being exercised through a mandate. The State is acting in its own name, as it has the right to expect other States to treat its nationals in a way that is compliant with international law.

\subsection{The damage suffered by the national vs the damage suffered by the State. In} cases related to diplomatic protection, it is often said that the State does not suffer a direct damage. We refer instead to an indirect damage, on the ground that one of its nationals was not treated in accordance with international law. However, this point of view does not seem to align with the PCIJ's position, since the Court clearly stated that the State's own right would be at stake in such a case. When a foreigner is frustrated in the exercise of his rights by a foreign State, there are actually two damages: one suffered by the foreigner as an individual, and one suffered by his/her Home State. We can thus consider that one act entails two damages that will both be repaired through diplomatic protection within the same procedure

1.008 The State's own right. When filing a claim in a case related to diplomatic protection, the State is acting in its own name, to defend its own right namely the right that its nationals receive a treatment that is consistent with the requirements of international law. This statement, in itself, confirms that international law confers rights to individuals, even if indirectly. Those individual rights could not be subject to a direct claim filed by private persons under international law, as only the Home State of the Claimant has the right to act in order to defend them. As we will see, the existence of such rights is nonetheless established.

8 PCIJ, The Mavrommatis Palestine Concessions, 30 August 1924, PCIJ Rep. Serie A n², p. 12. 


\section{(ii) Conditions for the exercise of diplomatic protection}

Applicable law. The conditions for the exercise of diplomatic protection in international law are not very specific or easy to identify. We should however mention them here, in order to understand how diplomatic protection has helped fulfil the purposes of investment protection. The International Law Commission (ILC) of the United Nations has been working on diplomatic protection for quite some time. It first considered introducing provisions about it in its Articles on the Responsibility of States for internationally wrongful acts. Eventually, diplomatic protection was treated in isolation and the ILC adopted draft articles on this matter in $2006 .{ }^{9}$

Discretionary power. We should first highlight that the exercise of diplomatic protection is a discretionary power of the State. It is never bound to file a claim on behalf of its nationals, even when asked to do so. That is why a foreigner's commitment not to ask for diplomatic protection from its home State would not be binding for the latter in any way. This is because the right to exercise diplomatic protection is that of the State only and no individual can take commitments related to it. As a consequence, a State can never be bound to exercise diplomatic protection. Nonetheless, as we will see further on, this constitutes one of the major drawbacks of this mechanism and might explain the reasons for its decline in international economic law today.

Diplomatic protection and nationality. Secondly, the exercise of diplomatic protection is subject to a core condition: the nationality requirement. Indeed, the State can only act if the rights of its nationals are being infringed. As stated by the PCIJ, "it is the bond of nationality between the State and the individual which alone confers upon the State the right of diplomatic protection'. ${ }^{10}$ Therefore, the exercise of diplomatic protection relies upon international rules on nationality, which are themselves the source of many issues. ${ }^{11}$ One must here stress the fact that international law requires an effective bond of nationality in order for the State to exercise diplomatic protection. That question was raised in the abovementioned case brought before the PCIJ. The ICJ only accepts diplomatic protection claims from States regarding their nationals, when the bond of nationality proves to be effective. ${ }^{12}$ This effectivity requirement is quite important in cases of double nationalities because in

9 Adopted by the International Law Commission during its fifty-eighth session, submitted to the General Assembly in its report on this session's work (A/61/10). The report containing the draft articles and their commentary has been published in ILC Reports, 2006, vol. II(2).

10 PCIJ, Panevezys-Saldutiskis Railway, 28 February 1939, PCIJ Rep. Series A/B, No. 76, p. 16.

11 See on this matter: Société française pour le droit international, Droit international et nationalité, Paris, Pedone (2012), p. 527.

12 ICJ, Nottebohm (Liechtenstein v. Guatemala), 6 April 1955, ICJ Rep. p. 4, p. 22. 
such a situation, two different States might have the right to exercise their protection. However, in most cases, only one nationality proves to be effective.

1.012 The nationality of legal persons. In international law, one of the most complex issues in terms of nationality rules has to do with legal entities. We will look further into this topic when we address the problem of the nationality of investors, but it can already be underlined that the law governing diplomatic protection is quite strict on this matter. ${ }^{13}$ Indeed, according to the Barcelona Traction judgment, ${ }^{14}$ only the State a society is a national of can exercise diplomatic protection for it. In that case, the ICJ indeed rejected the possibility for the State of nationality of the shareholders to exercise diplomatic protection, even if they possessed the majority of the shares. Here, 80 per cent of the Barcelona Traction shares were indeed held by Belgian shareholders, but the Court refused to grant Belgium any right to exercise diplomatic protection, since the company itself was not Belgian. Thus, only the nationality of the company matters, not the nationality of the majority shareholders. As the Court stated, only the company possesses 'rights', whereas the shareholders merely have 'interests': 'Not a mere interest affected, but solely a right infringed involves responsibility, so that an act directed against and infringing only the company's rights does not involve responsibility towards the shareholders, even if their interests are affected. ${ }^{15}$ In the same case, however, the Court admitted that the State shareholders are nationals of could exercise diplomatic protection in two instances: first, in cases where the society would have ceased to exist; secondly, when the State the company is a national of cannot act on its behalf, under international rules on the nationality of legal persons. ${ }^{16}$ But a limit was put on this second exception in the more recent Abmadou Sadio Diallo case. The Court ruled that a State cannot exercise diplomatic protection for the shareholders of a company when that company is a national of the State against which the claim is made: this protection "by substitution' has not (yet?) been recognized in international law. ${ }^{17}$ Such a rigorous approach can be questioned, but it is actually justified by the fact that shareholders are to be considered as investors, thus benefiting from the protection granted by thousands of treaties which also offer them a right to appear before an arbitral tribunal. Therefore, resorting directly to arbitration is far more interesting for them. In view of the above, the role played by diplomatic protection for the safeguard of economic foreign interests has

13 See infra, paras 5.009 et seq.

14 ICJ, Belgium v. Spain, 5 February 1970, ICJ Rep. p. 3.

15 Ibid., para. 46.

16 Ibid., paras 65 et seq.

17 Abmadou Sadio Diallo (Republic of Guinea v. Democratic Republic of Congo), Preliminary objections, 24 May 2007, ICJ Rep., p. 582, para. 89. 
necessarily become less important. That is why in the Diallo case, the ICJ considered that such a protection "would therefore appear to constitute the very last resort for the protection of foreign investments'. ${ }^{18}$ It would only be relevant when there isn't any possibility to go to arbitration, which is quite an exceptional situation.

The 'Clean hands' doctrine. There are additional requirements to benefit from diplomatic protection. First, the individual's conduct towards the host State must be appropriate. It is usually said that the individual must have 'clean hands', even though the exact meaning of this requirement is still quite ambiguous. One cannot be compensated for the damage one has suffered if that damage is self-induced, even if only to a certain extent. This stems from the rules on causation and responsibility, there is no need to resort to any other doctrine or set of rules. This being said, if the investor's conduct has not contributed to the damage he or she allegedly suffered, it is difficult to determine whether or not this conduct should be taken into account, regardless of it being non-compliant with the defendant State's domestic law or simply inappropriate. It is equally difficult to determine at which the stage of the process it should be considered. It is worth pointing out that the ILC did not mention the 'clean hands' doctrine in its draft articles on diplomatic protection. Such an omission could make us think that this doctrine is not a requirement under customary international law.

The exhaustion of domestic remedies. The plaintiff must have necessarily exhausted all domestic remedies before seeking diplomatic protection from his or her State. ${ }^{19}$ This requirement comes from the fact that international law does not take into consideration the State's domestic legal system. The conduct of a national body is not considered wrongful under international law, as long as another organ of that State - a judicial one, or of any nature - can review said conduct. In other words, the exhaustion of domestic remedies is a way for the State to address any eventual wrongful conduct and thus avoid being held responsible under international law. This is also a way to demonstrate that the breach of international law is real and can no longer be addressed. In that respect, of course, the plaintiff should only exhaust legal remedies (i.e., the legal remedies the plaintiff can access under domestic law). It is, indeed, widely accepted that if the claim is bound to be rejected or if the 
domestic judge will most likely discriminate against foreigners, such an exhaustion cannot be imposed as a condition for diplomatic protection. ${ }^{20}$

\section{(b) The weaknesses of diplomatic protection for the purposes of foreign investors' protection}

1.015 The inadequacy of diplomatic protection. We have mentioned earlier the main reasons why diplomatic protection might not be an efficient investment protection mechanism. Indeed, the very nature of this protection is likely to affect its overall effectiveness. There also seems to be a discrepancy between the institution of diplomatic protection and the actual protection that foreign investors are seeking. Three major weaknesses can be highlighted here.

1.016 The absence of a right to benefit from diplomatic protection. First, as mentioned before, the exercise of diplomatic protection is a choice of the State and of the State only. This stems from the fact that, when exercising diplomatic protection, the State acts for the protection of its own subjective right. It is thus free to act or to refrain from doing so for the protection of this right. However, this implies a constant uncertainty for the individual as to whether or not the State he or she is a national of is willing to exercise this protection. The State may absolutely refuse to do so on any ground, it being political, diplomatic, ideological or for any other kind of reason.

1.017 Modification of the dispute. Secondly, exercising diplomatic protection entails an internationalization of the dispute and therefore a change in its very nature. At first, the dispute is between an individual and a State, within the domestic legal system. The dispute becomes an inter-States one as soon as the State the plaintiff is a national of exercises diplomatic protection. The main drawback of this mechanism is that the individual which has been the victim of the host State's conduct is left aside and cannot intervene in the dispute. Furthermore, the requesting State will receive the compensation, if any, not the individual. Also, the compensation can only be made to repair the infringement of the State's right and not that of the individual. The individual might not get any compensation, especially considering the fact that in inter-State disputes, financial compensation is quite unusual.

20 See the Arbitration between Robert E. Brown (United States) v. Great Britain, 23 November 1923, UNRIAA vol. VI, 120, at pp. 127-9. Such a rule is also applied in regional mechanisms for Human Rights protection where the exhaustion of local remedies is a pre-requirement to appear before the Court. For instance, see Inter-American Court of Human Rights, Velásquez Rodriguez v. Honduras, 29 July 1988, ILR vol. 95 p. 259, paras 61-81. 
Modification of the reparation. Eventually, the shift from an Individual1.018 State to an inter-States dispute entails consequences as to the kind of reparation that can be granted by the judge. Indeed, reparations in inter-States disputes are more likely to be of a symbolic nature than of a monetary one. Also, an investor will usually seek financial compensation rather than a diplomatic symbolic reparation such as excuses or guarantees of nonrepetition. In a nutshell, diplomatic protection will not allow the investor to obtain the type of reparation he wants. That is probably one of the main reasons why diplomatic protection has not proven to efficiently protect foreign investments - which is why another system was put in place.

The persistence of diplomatic protection. Despite the weaknesses that we just described, diplomatic protection has not entirely disappeared from international investment law. Indeed, some old cases related to diplomatic protection still have a significant value as precedents today. ${ }^{21}$ This stems from the fact that in the 19th century, a large number of cases had to do with foreign investment. Indeed, many of these cases aimed at providing diplomatic protection for foreign economic agents. These precedents are therefore undoubtedly relevant for situations that we deal with nowadays. Besides, diplomatic protection has recently regained importance with a case involving Cuba and Italian investors. ${ }^{22}$ The legal basis for the claim was a bilateral investment treaty, which shows that such treaties do not set aside the States' right to exercise their diplomatic protection.

\section{On Mixed Commissions and the protection of foreign economic operators}

The need for additional protection. When it comes to creating a business abroad, history has shown that people will not normally try their luck on their own. Which is why we would usually find several investors of the same nationality in a given country at the same time. This phenomenon partly stems from colonial history. Indeed, many economic actors from the former colonial power would settle in the newly independent State to take part in the development of a new society. For that reason, any coup or radical political shift affecting the economic rights foreigners have obtained in that State would be likely to impact dozens or hundreds of individuals coming from the same country. In such a situation, creating an ad hoc court which would deal

21 See, e.g., the Delagoa Bay Railway Arbitration, 1898, in J. B. Moore (ed.), History and Digest of the International Arbitrations, vol. 2, p. 1865.

22 Ad hoc arbitration, Italian Republic v. Republic of Cuba, Preliminary Award, 15 March 2005, Final award, 15 January 2008. 
with the claims filed by all the nationals of one country is a lot more convenient than letting individual claims accumulate before different courts. That is the exact reason why States created Mixed Commissions, which inevitably took part in the elaboration of international rules to protect foreigners. That is why we can safely say that these Mixed Commissions largely contributed to the emergence of contemporary arbitral tribunals.

\section{(a) The origin and development of Mixed Commissions}

1.021 The emergence of the first Commissions. The first Mixed Commissions were established by the Jay treaties, signed in 1794 between the United States and Great Britain - which proves that this concept is not entirely new. The purpose of these neutral Mixed Commissions was to deal with the significant amount of claims that arose from the US independence process at the end of the 18th century. The Commissions' composition is quite simple: each Commission consists of the same number of commissioners from each of the States involved in the dispute. An umpire is also appointed to rule in the event of a tie vote. This is undoubtedly the first attempt that was made to institutionalize international litigation, which will then fully develop in the second half of the 20th century.

1.022 The Jay Treaties Commissions. The first of the Jay treaties was signed on November 19, 1794. It established three commissions to settle several disputes that had arisen between the US and Great Britain. ${ }^{23}$ The first Commission is of little interest here, as it only covered purely inter-State border issues. The second and third Commissions, though, may be of relevance to investment law. The second one was indeed created specifically to hear cases that had to do with sums of money American citizens owed British citizens. The third one dealt with granting compensation after goods and vessels belonging to American and British citizens were taken away. We can therefore highlight that the Commission which is largely considered as the first international 'court' dealt, at least partially, with claims involving individual rights.

1.023 The functioning of the Mixed Commissions. After the Jay Treaties, resorting to the Mixed Commission became increasingly common. Foreign nationals who had a high moral authority would often be appointed to the role of umpire and would nearly act as sole arbitrators. This tendency to give larger powers to umpires is confirmed by the fact that commissioners usually played a less important role in the process. Indeed, commissioners mainly acted as

23 Treaty of Amity, Commerce, and Navigation, Between His Britannic Majesty and the United States of America, 19 November 1794. Text in H. La Fontaine, Pasicrisie internationale, The Hague, Nijhoff, (1997), p. 1. 
negotiators defending their State's interest and trying to reach a commonly acceptable agreement. Yet, if they failed to do so, the umpire would rule alone. Being the only member of the Commission designated as an 'arbitrator', the umpire was the only one to act as a judicial authority given that he was the only one to decide on the basis of the law, being the only one to have a neutral approach towards the parties. Mixed Commissions can therefore be considered as the forerunners of arbitral tribunals, although these two methods of dispute settlement are quite different. Not to mention the fact that in general, the solution proposed by the Commission would have to be accepted via an agreement reached between the two disputing States. This is why the Commission couldn't truly be considered as a judicial authority that issued mandatory decisions. This process was indeed more similar to mediation and nevertheless proved to be quite efficient.

The development of Mixed Commissions until the 20th century. Several Mixed Commissions with variable lifespans were created after 1794, especially in the second half of the 19th century. A few examples are worth mentioning. One of these commissions was set up between the US and Mexico by means of a treaty signed in 1839. It was created to hear the claims filed by US citizens against the Mexican Government regarding confiscation and expropriation measures the latter had taken against these citizens' property. ${ }^{24}$ The Commission consisted of four commissioners (two nationals of each State) and the umpire who was initially the Prussian emperor, but eventually delegated his mission to his ambassador in Washington D.C. Without claiming to be exhaustive, we can also mention the Commission created between France and Venezuela which consisted of two commissioners and the Queen of the Netherlands acting as the umpire, 25 the Commission established between Germany and Venezuela in which the umpire was to be named by the President of the US, ${ }^{26}$ or the Commission created between Italy and Venezuela to deal with issues regarding the treatment given to Italian nationals by Venezuelan authorities. ${ }^{27}$ Mixed Commissions have proven to be necessary even during the 20th century, especially in the context of the Mexican revolution which took place between 1910 and 1920 and led to the violation of the rights and property belonging to western citizens living in Mexico. For

24 Treaty signed on 11 April 1839, La Fontaine, Pasicrisie internationale, at 21.

25 Protocol signed on 27 February 1903, UNRIAA vol. X, p. 3.

26 Protocol signed on 13 February 1903, UNRLAA vol. X p. 359.

27 Protocol signed on 13 February 1903, UNRIAA vol. X p. 479. 
example France ${ }^{28}$ and the UK, ${ }^{29}$ among others, negotiated the creation of such Commissions in the 1920s in order to address the claims issued by their nationals.

1.025 The evolution of Mixed Commissions after 1945. The shift that occurred with the Second World War did not affect the development of Mixed Commissions, even though they naturally became less relevant with the emergence of permanent dispute settlement mechanisms. We can mention for example a Commission established by the US and Austria in order to deal with claims regarding bonds belonging to US citizens, issued in US dollars in Austria. ${ }^{30}$ In the end, dozens of Mixed Commissions were created over the course of the 19th and 20th centuries, among which only a few have been mentioned here. They inevitably left a mark which is still visible in the dispute settlement mechanisms that are in place today.

\section{(b) The legacy of the Mixed Commissions}

1.026 The relevance of this legacy. Over two centuries, Mixed Commissions have contributed to the emergence of a wide range of rules and principles, both on procedural and substantive matters. Indeed, their purpose was to hear individual claims filed by the State of the claimants, regarding the treatment they were given on the territory of a foreign State. The Commission therefore inevitably had to deal with the protection of aliens and thus contributed to the creation of international rules in this field. The Commissions then not only applied the rules for the protection of foreigners, but they also participated in their development and helped adapting them to social changes. We can therefore say that Mixed Commissions have contributed to establish the basis of contemporary international investment law, even if most of the time their decisions were issued in specific contexts. Yet, different sets of rules are rooted in the case-law of these Mixed Commissions and can be identified as such.

1.027 Rules on compensation. The third Jay Treaty Commission was created to compensate UK and US citizens for the damages they suffered during the US war of independence. It heard 536 cases and issued decisions on financial compensation, based on the compensation agreement that had been reached between the States involved in the dispute. We can see that these Commissions already used certain basic principles which still guide the courts in their decision-making nowadays. Some of these principles are: the obligation for the State to provide adequate compensation for the losses it caused; providing 
financial compensation when restitution is not possible; compensation in a currency which can be immediately used by the beneficiary (in that case, the compensation would either be in US Dollars or in British Pounds, depending on the nationality of the claimant). Nowadays, these principles are indisputable and they form the basis of international rules of reparation. ${ }^{31}$ It is thus worth mentioning that they were already being applied back at the end of the 18th century.

The protection of individuals. Other more specific rules stemming from the Mixed Commissions' case-law are still often applied today. For example, in several cases, the Commissions found arbitrary arrests and/or detentions to be contrary to international law. This is how they participated in the emergence of principles and rules of protection of individuals, at a time when the mere existence of such rules was still quite uncertain. For instance, this is why putting an alien in detention without any legal basis in domestic law has long been considered as an internationally wrongful act. ${ }^{32}$ It has also been long established that if a foreigner's property was to be affected by civil unrest, the host State would be held responsible for it even though it did not directly cause the damage. ${ }^{33}$ Both rules were established quite early by the Mixed Commissions.

The emergence of a minimum standard of treatment. In a more general way, the input of the Mixed Commissions to contemporary investment law is twofold. From a substantive point of view first, they have clearly contributed to defining the content, at least in broad terms, of the minimum standard of treatment of aliens required by general international law - which includes in particular the obligation to respect the physical integrity of the person, the respect for property and the prohibition of denial of justice. ${ }^{34}$ These standards are fully upheld today. As for the procedural - and second - aspect, the Commissions have certainly introduced the idea that a private person did not only hold rights in international law - this idea, as we know, can be traced back to Grotius and even to earlier times - but that it must also be able to benefit from mechanisms enabling it to assert these rights. In their practice, Mixed Commissions strongly supported the implementation of individual complaints in international law. Such complaints later multiplied before

31 See, e.g., R. Higgins, 'The taking of property by the State', The Hague Academy of International Law Recueil des Cours - Collected courses vol. 176, 1982 (III), 259-391.

32 Mixed Commission France / Venezuela, Rogé, 1902, UNRIAA vol. X, p. 13.

33 Mixed Commission Germany / Venezuela, Kummerow et al., 1903, UNRIAA vol. X, p. 369.

34 For a classic presentation of the substantive rules, see D. Anzilotti, 'La responsabilité internationale des Etats à raison des dommages soufferts par les étrangers', 13 RGDIP 5-29 (1906). 
regional courts in the field of human rights but also before arbitral tribunals that ruled on the basis of investment protection treaties. ${ }^{35}$

\section{The development of arbitration}

1.030 Non-judicial nature of Mixed Commissions. One might say that arbitration represents the judicial extension of the Mixed Commissions and their practice. Indeed, the Commissions did not entirely fulfil the mission of a judicial entity for three reasons. First, the negotiation between commissioners was given great significance, in such a way that Commissions could be compared with conciliation or mediation bodies rather than with proper judicial entities. Secondly, the decision taken by the Commission would generally have to be endorsed by an agreement between the two States to become binding, which makes it similar to a negotiated settlement. Finally, commissioners are appointed to act in the interest of their State, whereas a judge acts independently, even if he is a national of a State party to the dispute. Therefore, Mixed Commissions were far from the independent third-party decision-maker that a judicial entity is supposed to be.

\section{(a) Resorting to arbitration}

1.031 The need for arbitration. Mixed Commissions and arbitral tribunals are different in many respects. Mixed Commissions were set up to cope with an influx of applications relating to a single situation. Their purpose was therefore to centralize requests to establish a coherent and systematic handling mechanism. On the other hand, an arbitral tribunal is generally invested with only one mission: to settle a dispute in a single case, even if there may be several applicants. The arbitral tribunal, therefore, has no permanent existence: it is ad hoc by nature, and disappears once the case it was handling is settled. This explains why arbitration developed simultaneously to the Mixed Commissions and not successively.

1.032 The long-standing existence of arbitration. Arbitration has been used to settle inter-State conflicts such as border disputes ${ }^{36}$ or issues regarding exchanges of goods. However, many cases also involved the individual rights of foreigners. Therefore, arbitral tribunals, just like Mixed Commissions, had to decide on compensation matters when the individual rights of foreigners

35 Yet, the relationship between the minimum standard of treatment and investment treaties is ambiguous. See Martins Paparinskis, The International Minimum Standard and Fair and Equitable Treatment, OUP (2013). See also infra, paras 9.006 et seq.

36 See, e.g., the arbitration instituted by the agreement of December 14, 1814 between the US and Great Britain, La Fontaine, Pasicrisie, 7. 
had been affected by a State. The first observable trend was to entrust the task of arbitration to a foreign head of State. However, a head of State does not necessarily have a legal background and as a result, their decisions could be somehow startling. One can mention, as an illustration, the award issued in 1852 by Louis Napoléon, then President of the French Republic, regarding a dispute between Portugal and the US on the compensation payable by the Portuguese Government to certain American citizens. ${ }^{37}$ It is hard, when reading the award, to see on which legal basis it is grounded: it seems to be grounded on the personal feeling of the arbitrator rather than on a real legal reasoning.

The professionalization of arbitration. In order to cope with the increasing difficulty of some cases, the heads of States acting as arbitrators took the habit of entrusting the judgment to better qualified people, being lawyers or experts on the subject-matter of the dispute. The arbitrator thus formally remained the author of the award, which was important in order for the decision to have moral authority, while actually relying upon informed opinions to produce a decision which was legally solid and likely to effectively put an end to the dispute.

The evolution of arbitration. Today, asking a head of State to act as an arbitrator has become extremely rare (whereas it is still frequent for them to act as a mediator or as a conciliator). This does not mean that arbitration awards are no longer rendered by only one person: they still are, but nowadays the arbitrator is appointed on the basis of his legal background and not of what he represents. We can mention narrowing it down to one case that is particularly relevant for investment law - the award issued by Prof. René-Jean Dupuy in the Texaco case, to which we will come back later. Prof. Dupuy was appointed as an arbitrator for his excellent reputation as a lawyer in international law. Here lies the main reason for the existence of arbitration: the parties want to submit their case to someone who has the technical ability to adequately deal with it. ${ }^{38}$

The growing success of arbitration. Given the lack of central authority in international relations, arbitration quickly emerged as the most frequently used mode of dispute resolution during the 19th and the early 20th centuries. It is indeed understandable that, absent any sustainable or mandatory authority to settle disputes, States preferred to resort to arbitration, in which they could both appoint the arbitrators and decide the applicable rules.

37 Ibid., 30-31.

38 Texaco Overseas Petroleum Company / California Asiatic Oil Company v. Libyan Government, January 19, 1977, 104 JDI 350 (1977). 
(b) The evolution of arbitration

1.036 Institutionalization. From the very beginning of the 20th century, several large-scale initiatives have come to structure contemporary international relations. Some of them aimed at creating permanent systems of dispute resolution and cooperation through universal organizations. The League of Nations was a first attempt, that eventually failed but which was far from being useless. Arbitration could be expected to follow a similar trend, by institutionalizing itself without losing its spontaneous and flexible character.

\section{(i) The Permanent Court of Arbitration}

1.037 Establishment. In the context of this trend towards institutionalization, the prevailing pattern was that of an arbitral tribunal composed of an odd number of arbitrators and operating fully in the manner of a court, particularly with regard to the independence vis-à-vis the parties. The creation of the Permanent Court of Arbitration (PCA) in 1899 illustrates this trend. The Court was created as an international organization by the Convention for the Pacific Settlement of International Disputes during the first Peace Conference held at The Hague, where the Court has had its seat since that date. ${ }^{39}$ The founding Convention was revised in 1907 during the Second Peace Conference. ${ }^{40}$ The PCA is not a court strictly speaking, since it is composed of an Administrative Council, a Secretariat and a number of arbitrators, who may be called to sit in arbitral tribunals. The PCA thus operates as an (international) administrative body allowing the disputing parties to submit their dispute to arbitration avoiding the need to define arbitration rules, to choose a seat, etc. It is, therefore, a facilitation body for the use of arbitration rather than a fullyfledged judicial body. Interestingly, this remedy is open to both States and private parties.

1.038 The appointment of arbitrators. The so-called 'members of the Court' are actually potential arbitrators, who will sit as such only if they are appointed. Each Member State may appoint up to four arbitrators for a period of six years. In case of a dispute, the parties can choose among those members the ones to whom they want to submit their case. More recently, in 2001, Optional Rules for the arbitration of disputes over natural resources and/or the environment were adopted. ${ }^{41}$ They include a list of arbitrators that are specialized in this field, who may be called upon to settle disputes involving

39 Convention pour le règlement pacifique des conflits internationaux, 29 July 1899, PCA Basic Documents 3. The French version of the convention is the authoritative one.

40 Convention pour le règlement pacifique des conflits internationaux, 18 October 1907, PCA Basic Documents 17.

41 Optional Rules for Arbitration of Disputes Relating to the Environment and/or Natural resources, 2001, PCA Basic Documents 179. 
environmental or natural resources issues. It is an important reform, as environmental issues hold a significant place in transnational disputes. The PCA thus continues to play a central role in the future of international investment law.

The importance of the PCA. The PCA quickly established itself as a key judicial entity, especially through the issuance of certain awards that are still of great importance today. For example, it was a PCA arbitral tribunal that dealt with the case of the Norwegian Shipowners in which a Norwegian shipping company filed a claim for compensation after the requisition of some of its ships by the US Government during the First World War. ${ }^{42}$ Today, the courts still consider this award as a landmark case in the field of foreign property protection, an area which is of primary importance in investment law. ${ }^{43}$

\section{(ii) The institutional development of arbitration since 1945}

The creation of ICSID. As in many other fields of international law, the most important evolutions occurred after 1945. In particular, the International Centre for Settlement of Investment Disputes (ICSID) was created by the Washington Convention in $1965^{44}$ in order to resolve disputes between foreign investors and States on the basis of State contracts, before breaking away from this type of contract and establishing itself as the main judicial entity in this field. ${ }^{45}$ Details on the operation of the Centre will be discussed below, in Part C. But for the time being, we can say that the ICSID's creation was characterized by a subtle mix between audacity and continuity.

Continuity of the evolution. The emergence of ICSID draws on a certain institutional continuity. Indeed, the creation by States of a supranational body to settle disputes is nothing new. The ICSID Convention is part of a general trend towards institutionalization which began in the 19th century, as we saw above, in particular with the establishment of the PCA.

Audacity. The main innovation brought by the Washington Convention is 1.042 laid down in its Article 36(1), which provides that the request for arbitration may be addressed to the Secretariat not only by a State Party but also by one of its nationals. Therefore, the Convention gives private persons an access to an international judicial entity in a systematic manner. A situation which used to be exceptional, in addition to being very rare in practice, thus became a

42 Norway v. United States, August 13, 1922, I UNRIAA 309.

43 See, e.g., Siemens A.G. v. the Argentine Republic, ICSID Case No ARB/02/8, Award, 6 February 2007, para. 267.

44 Washington Convention of 18 March 1965, 575 UNTS 159.

45 See infra, paras 1.046 et seq. 
principle in the context of ICSID. In this respect, this is a fundamental evolution, which will take a step further in the early 1990s. ${ }^{46}$

1.043 Other arbitration rules. Even if it has become the most important institution as to the number of cases, ICSID is not the only one allowing private persons to go before an arbitral tribunal against a State. For example, the Arbitration Rules of the United Nations Commission on International Trade Law (UNCITRAL), adopted in $1976^{47}$ and revised in 2010 and 2012,48 provide the framework for many transnational arbitrations, including in the context of the North American Free Trade Agreement (NAFTA) which explicitly refers to those rules. ${ }^{49}$ The UNCITRAL rules do not include a list of arbitrators or a seat, but they obviously facilitate the recourse to arbitration for the settlement of disputes, particularly in investment matters.

1.044 Other arbitration institutions. In addition to the PCA and ICSID, there are several other institutions in charge of dealing with arbitration proceedings. There is an Arbitration Chamber in the International Chamber of Commerce in Paris (ICC), a London Court of International Arbitration in London (LCIA) and an Arbitration Institute of the Stockholm Chamber of Commerce (SCC). These three institutions, to which we will come back in the third part of this book, actively participate in the development of case-law. They also form part of the trend originated by ICSID, an Institution which itself illustrates an evolution that is several hundreds of years older than international law.

1.045 Continuity. With this brief overview, we can clearly see that the very idea of protecting foreigners and their property is not new. The need to set up institutions to protect these rights has also been long-standing, and several of them have been established from the early 20th century. Therefore, contemporary investment law was not born ex-nibilo and is naturally part of a historical continuity.

46 On this evolution, see infra, paras 1.092 et seq.

47 The rules were adopted by the United Nations General Assembly on 15 December 1975, AG/RES/31/98.

48 The 2012 revision only introduced a transparency requirement in the 2010 rules but did not introduce any other change. The 2010 Rules were adopted by the General Assembly Resolution AG/RES/65/22 of 6 December 2010; the 2012 Rules by Res. AG/RES/68/109 of 16 December 2013.

49 NAFTA was signed on 17 December 1992, 32 ILM 289 (1993). It may be replaced by a new agreement called United States-Mexico-Canada Agreement (USMCA) adopted on 30 September 2018 but not yet in force. See infra, para. 9.012. 


\section{B. THE EMERGENCE OF STATE CONTRACTS}

Historical context. In the context of the industrial revolution, many individuals have sought to develop economic activities in foreign States, where the legal system and the government were not always very stable. They could benefit from the guarantees provided by arbitration or Mixed Commissions, but those guarantees had two main flaws: first, the establishment of these bodies or settlement systems depended first and foremost on States. Therefore, there was never any guarantee that such institutions would be set up. Secondly, these settlement methods were always used a posteriori. Thus, they were unlikely to have any deterrent effect as to the treatment given to foreign operators. This is why investors - who were not yet qualified as such - started signing contracts with States, in which they would gradually introduce dispute settlement clauses to provide for the possibility of recourse to arbitration. This ensured the possibility for them to get protection from a supranational body in case of difficulty. Meanwhile, those provisions were also a way of encouraging States to be cautious, knowing that they could be sued before an independent body in the event of inappropriate conduct.

\section{Appearance and development of State contracts}

First approach. State contracts are agreements signed between a State and a foreign private person, to which international law is applicable. ${ }^{50}$ Their appearance stems from an evolution we should recount in order to understand why these contracts played such a fundamental role. This would also help our understanding of how the relationship between foreign investors and States became gradually subject to international law.

\section{(a) The existence of contracts between foreign private persons and States}

A long-standing practice. There is nothing new or groundbreaking in a contract signed between a State and a foreign private person. Such contracts were already quite common in the 19th century, for obvious practical reasons: when it comes to the exploitation of a mine or the undertaking of public work by a private person, the need for a contract is quite clear in order to clarify the rights and obligations of both parties, whatever the nationality of this private person. This is all the more relevant since the first investment operations generally concerned issues requiring the use of this type of instrument. It was quite frequent at the time to entrust the construction of large infrastructures essential to the construction of a modern State to foreign companies: railroads,

50 See, in general, J. F. Lalive, 'Contrats entre Etats ou entreprises étatiques et personnes privées', The Hague Academy of International Law Recueil des Cours - Collected courses vol. 181, 1983 (III), 9-284. 
train stations, roads, bridges, canals or tunnels, etc., or the exploitation of natural resources. In all of these cases, the foreign operator is only a provider for the State, in the context of a classic economic relationship. The contract is thus a simple and clear necessity. Bearing this in mind, it is easy to understand the key role delegations and concessions played in the emergence of State contracts.

1.049 The application of domestic law to State contracts. At first, such contracts were subject to the domestic law of the host State and as a result, disputes were brought to domestic courts. This solution nevertheless entails a number of risks, especially regarding the legal instability of the host State and the insufficient impartiality of some domestic judges. Such a situation, however, did not preclude the recourse to arbitration: there are some examples, admittedly rare, of compromise agreements signed between States and private companies, establishing an arbitration system based on a contract signed between the two parties. This was the case, for example, of the award issued by Napoléon III (who was Emperor at this time) in a dispute between the Universal Company of the Suez Canal and the Viceroy of Egypt. The conflict stemmed from an amendment introduced by the government to a regulation the foreign enterprise was subject to, on the basis of an arbitration agreement signed by the parties after the dispute had arisen. ${ }^{51}$

1.050 Indifference towards the issue of applicable law. This case shows us that there are long-standing examples of contracts signed between a private person and a State he or she is not a national of, on the basis of which an arbitration was set up. However, this type of agreement is not yet a real State contract since the crucial question, that of the applicable law, remains unsolved at this stage. In the Universal Company of the Suez Canal case, the arbitrator did not even address this issue and instead applied rules of unknown origin. Besides, this uncertainty confirms the need to resort to professional lawyers when dealing with such cases.

1.051 The generalization of arbitration. In any event, private persons had very limited access to arbitration, except when explicitly provided by the applicable contract. That is why economic agents began to introduce arbitration clauses in the contracts they signed with foreign States. Such provisions were rare at the beginning but as they started being introduced more and more frequently, they ended up becoming systematic. This is how a right to resort to arbitration was progressively recognized to private persons on a case-by-case basis, at least

51 Award of April 21, 1864, La Fontaine, Pasicrisie, p. 122. 
when they had signed a contract with a foreign State. ${ }^{52}$ Yet in many cases, the issue of determining the applicable law remained unsolved.

\section{(b) The application of international law and the emergence of State contracts \\ (i) The issue of determining the applicable law}

The legal issue. Resorting to arbitration for the settlement of disputes between States and foreign nationals certainly strengthens the protection of private investors, but is not enough on its own to protect them against all arbitrariness. Indeed, one core aspect of the question is also the issue of applicable law. Let us take the example of a neutral and impartial authority, which is however required to enforce badly drafted, obscure or arbitrary norms: the protection provided by such an authority would therefore be inefficient. That is why in many cases, it is best to avoid resorting to domestic law. Especially when the national law of the host State is insufficiently developed regarding the subject-matter of the disputes, as it leaves the arbitrators to decide a case without being able to rely on specific rules, ultimately leading them to decide according to their sole subjective judgement, which is far from guaranteeing a real security for investments. In addition, the domestic law of the host State remains entirely within the control of its government, which can decide at any time to amend it, in a way that could be unfavorable to the investor and without providing the latter with any form of compensation.

Contracts and domestic law. The abovementioned difficulty was further

heightened by the well-known principle according to which 'Any contract which is not a contract between States in their capacity as subjects of international law is based on the municipal law of some country. ${ }^{53}$ It means that a contract, such as the one we have mentioned thus far, can only be subject to domestic law, under the referral rules that exist in private international law. The French Cour de Cassation had itself referred to this concept in the case of the Messageries Maritimes, stating that 'every international contract is necessarily connected to the law of a State'. ${ }^{4}$ This situation is not controversial per se, and one might even conclude that the domestic law of the State the investor is a national of should in any event apply to all contracts signed by a State and a foreign investor.

52 For examples of contracts and disputes settled by arbitration, see J. G. Wetter and S. Schwebel, 'Some little-known cases on concessions', BYBIL 183-232 (1964).

53 PCIJ, 12 July 1929, Serbian and Brazilian Loans, Series A, No. 20, 41.

5421 June, 1950, Rev. Crit DIP, 1950, 609. 
1.054 Private international law. However, contracts are above all subject to the law the parties decide to apply or, absent any choice, the law the contract is more closely connected to. Nevertheless, both cases involve significant challenges: according to the rules on connecting factors, the State with which the contract has the closest connection is the one where the operation takes place. In other words, the law of the host State will apply, that is to say the one from which the foreign investor seeks to escape for the reasons that have been mentioned above. As to the will of the parties, the investor is very likely to be tempted to choose the law of the State he is a national of. But it is even more likely that the host State will object to this solution, especially since it does not itself maintain any relationship with the other State, their only existing legal connection being through a national of that State. Also, a State would be quite unlikely to accept that a contract which is being executed on its territory would be subject to the law of another State. The solution, therefore, could only be found in the application of a law that is neutral vis-à-vis both parties. One could naturally think of the domestic law of a third State, and this solution could be adopted, but it may also raise practical difficulties since the chosen arbitrators would frequently and understandably misunderstand this law. Therefore, little choice is left, as there remains only one set of rules with the highest degree of neutrality from this point of view, equally accessible to all arbitrators of all nationalities: international law. This is how international law progressively established itself as the set of rules governing investor-State contracts, a development which resulted in the emergence of 'State contracts'.

\section{(ii) The internationalization of State contracts through contractual practices}

1.055 Methods. The parties are above all the ones who control what is laid down in the contract and who have the possibility to determine which law applies to it, or would be applicable in case of litigation arising from its execution. In the contractual practice, mainly two methods have been used to internationalize the relationship stemming from the agreement: one being direct and the other being indirect but nonetheless just as effective.

\section{Direct internationalization: the will of the parties}

1.056 The freedom of the parties. It must first be recalled that contractual freedom implies an almost complete liberty of the parties on a large number of issues, the first being applicable law. They therefore have the possibility, in order to achieve greater neutrality and thereby protect their legal relationship, to choose international law. The interest of such a choice is two-fold: for the private party, it means the absence of submission to the law of the receiving State and thus the neutralization of the 'political risk' by which it would expose itself to the good will of the local government authorities. For the host State, it means that a neutral set of rules will be applied, in the sense that it will not be 
the law of any other State. Indeed, as international law is an inter-State law, the receiving State has necessarily participated in its construction, acting in its capacity as a State. One may indeed recall that 'The rules of law binding upon States therefore emanate from their own free will as expressed in conventions or by usages generally accepted as expressing principles of law. ${ }^{15}$ This is why we can safely say that the host State has accepted the rules set out in international law, even if it did so indirectly. Therefore, subjecting a contract signed between this State and a foreign investor to international law seems perfectly acceptable.

An illustration: ICSID. The parties enjoy complete freedom when deter1.057 mining which law is applicable to the contract. This is best illustrated in the context of ICSID which was established by the Washington Convention, and was originally intended to offer an arbitration system on the basis of State contracts. The famous provision of Article 42(1) of this Convention stipulates that 'The Tribunal shall decide a dispute in accordance with such rules of law as may be agreed by the parties.' The provision goes on by mentioning alternative solutions to cover an absence of choice by the parties. The parties' freedom thus appears as a core principle here, especially since in arbitration, the tribunal remains mainly dependent on what has been consented by the litigators.

The application of international law. When the parties do make a choice, 1.058 they usually give an important role to international law. Yet, international law is generally chosen along with the law of the host State. Referring only to international law seems actually quite rare in practice. In such cases, however, arbitral tribunals tend to apply domestic law only subject to its conformity with international law, which ultimately amounts to the application of the latter. ${ }^{56}$ Even if the ways to articulate international law with domestic law vary, they ultimately lead to the same result, which is to subject the investorState relationship, if not to 'pure' international law, at least to a domestic set of rules which is compliant with international law. The stability of the investorState relationship is anyhow achieved whether or not international law is directly applied to the contract, since the amending power of the host State is neutralized in both cases. ${ }^{57}$

International law in the ICSID Convention. If the parties fail to choose which set of rules applies to the contract, the ICSID Convention sets forth a

55 PCIJ, 7 September 1927, The Case of the SS 'Lotus', Series A, No. 10, 18.

56 See infra, paras 1.069 et seq.

57 For examples of contractual clauses of this type and of the different methods, see Leben, supra, note 3, at pp. 270 et seq. 
similar solution. Its Article 42 provides that the tribunal shall enforce the law of the host State 'and such rules of international law as may be applicable'. We will come back to the exact meaning of this wording, but for the time being we can stress the fact that international law is involved even in the default solution offered by the Convention. A variation of that same option is the possibility for the parties to apply the aspects of domestic law that are compliant with international law. Such a case allows for formally maintaining the application of domestic rules, while substantially, the standards being enforced by the arbitrators belong to international law standards. This solution still raises problems, as seen in the awards issued against Libya after Colonel Gaddafi came to power and nationalized all the foreign-owned oil companies. There is no doubt that these three awards have largely contributed to the internationalization of State contracts. ${ }^{58}$

1.060 Domestic law and internationalization. However, despite all the possibilities mentioned above, the parties can always chose to apply the domestic law of the host State. Certain domestic systems provide all the guarantees of stability and impartiality that a foreign investor may be entitled to expect. In such a case, the arbitral tribunal will have no choice but to apply the domestic law of the receiving State. However, in any other circumstance, international law remains applicable in one way or another. Also, most domestic systems include international law standards in the domestic set of rules which is applicable on their territory. Therefore, when parties choose to apply domestic law to their contract, international law standards still apply. This is how contractual freedom led to the emergence of a new type of contract, subject to international law (even if partially). Today these agreements are referred to as State contracts.

Indirect internationalization: stabilization or equilibrium clauses

1.061 Clauses and applicable law. The contracting parties may not have chosen the law they want to apply in the event of a dispute. In such a case, the law of the host State will generally apply, but usually with certain boundaries. Contracting parties indeed started introducing provisions aiming at 'freezing' the host State's law therefore turning an ordinary contract into a State contract. In a nutshell, there are two types of such clauses.

1.062 Stabilization clauses. The stabilization clause is a provision which results in 'freezing' the applicable domestic law of the host State. It provides that the domestic law of the host State will apply as it stood at the time of the Company / California Asiatic Oil Company v. Libya, January 19, 1977, 104 JDI 350 (1977); Libyan American Oil Company (Liamco) v. Libya, April 12, 1977, Revue de l'Arbitrage 1980, 132. 
contractual commitment. This time is usually the date the agreement comes into force. It thus excludes the application of any subsequent modification made to the domestic law in question. The purpose of the clause is therefore to protect the contract by prohibiting the State from modifying the applicable national law. It is in this respect a serious guarantee for the foreign investor.

Equilibrium clauses. The equilibrium clause is less demanding on the host 1.063 State. Indeed, the latter still has the power to change its own law but these amendments are inapplicable to the contract. The clause also provides that if such changes affect the equilibrium of the contract, the other contracting party is entitled to compensation. Within the framework of the contract, the interest of such stipulations is twofold: they allow the State to preserve its general normative power, while at the same time protecting the foreign investor from the effects of the exercise of this power.

The relationship between clauses. The distinction between these two clauses is not always very clear in practice. Some provisions can also be qualified as 'hybrid clauses' since they combine both of the aspects that we mentioned earlier. ${ }^{59}$ In any event, these different provisions represent an interesting compromise between the application of the domestic law of the host State and the protection of the foreign investor. Nevertheless, the way in which such provisions have participated in the internationalization of the contracts in which they were introduced is yet to be fully explained. ${ }^{60}$

Doctrinal controversy. An important and particularly stimulating debate has emerged about the nature of these clauses, their validity, and their effects. ${ }^{61}$ The issue is to determine the extent to which a State can enter into such an undertaking, and if so what its exact legal value may be. Two essential reasons might indeed call into question the validity of these clauses. First, the fact that a change in the domestic law of the host State would be rendered void by the stabilization clause, at least in the context of the contract. Thus, the former domestic law would apply to the contract, even though it no longer exists in the applicable law of that State. Therefore, the situation is close to that of a contract with no governing law ('contrat sans loi'): a contract in which the governing law is entirely defined by the parties and is limited to the clauses.

59 M. Maniruzzaman, 'The pursuit of stability in international energy investment contracts: A critical appraisal of the emerging trends', 1(2) Journal of World Energy Law and Business, 121 (2008).

60 See, in general, P. Weil, 'Problèmes relatifs aux contrats passés entre un Etat et un particulier', The Hague Academy of International Law Recueil des Cours - Collected courses vol. 128, 1969 (III), 95-240.

61 See P. Mayer, 'La neutralisation du pouvoir normatif de l'Etat en matière de contrats d'État', 113 J.D.I (Clunet), 5-78 (1986); P. Weil, 'Les clauses de stabilisation ou d'intangibilité insérées dans les accords de développement économique’, Mélanges Ch. Rousseau, 1974, 301-28. 
The vast majority of the doctrine in private international law is hostile to such a situation because of the dangers it entails for the weaker party. ${ }^{62}$ The second reason is that the very possibility for a State to make such a commitment can be questioned from a legal point of view. Indeed, a State has, by nature, the power to undo what it has done. This is precisely where the 'political risk' against which the foreign investor legitimately seeks to protect himself lies. But strictly legally speaking, what a government has done, another government can undo. We can then question the very value of that commitment, since it is very difficult to imagine that a State would get rid of such a sovereign attribute which enables it at any time to amend its own law.

1.066 The internationalization of the contract. Including stabilization or equilibrium clauses has an effect on the nature of the contract. Indeed, it has been argued that a commitment not to modify its own law is legally possible for a State only if such commitment is made in the international legal order, i.e., if it is subject to international law. ${ }^{63}$ It is true that in its own legal order, a government can make a commitment but it will always be able to take it away: one administrative act may replace another, a bill may modify legislative provisions, a constitution may be revised. Whereas a commitment made in the international legal order will necessarily entail liability when it is violated. What has been done in the international legal order can only be undone in that same legal order. That is why the commitment made by a State not to modify its law would be meaningless in domestic law and can only have a real effect in international law. Therefore, any contract including a stabilization clause can be considered as inherently rooted in international law, otherwise it would not produce its full effect.

1.067 The determination of applicable law. The law which applies to a contract including a stabilization clause is thus a 'frozen' or 'stabilized' version of the domestic law of the host State. Since this set of rules is protected against any change, the host State does not have the power to modify it. As a consequence, since this set of rules escapes the host State's authority, it does not have much to do with its domestic law. This is certainly not enough to consider that these rules formally belong to international law, but the situation does resemble the application of the latter to the contract. It is indeed understandable that the investor would only accept the application of a 'frozen' domestic law of the host State if the latter provides enough guarantees.

\footnotetext{
62 See in French private international law, P. Level, 'Le contrat sans loi', Travaux du Comité français de droit international privé, 1967, 209.

63 Mayer, supra, note 61
} 
Otherwise, he would most likely opt for the application of international law to the contract.

Conclusion. By means of these different provisions, States and investors have 1.068 been able to internationalize their relationship, without necessarily having to openly choose to apply international law to the contract. It is certain that such practices have largely contributed to the emergence of international investment law, laying the foundations for the development of international protection rules of foreign economic actors.

\section{(iii) The internationalization of State contracts through arbitral practice}

The role played by adjudicators. The contracting parties do not always necessarily decide (directly or indirectly) whether or not international law applies to the contract. They can also choose to apply international law partially, or even remain silent as to its role in the event of a dispute. It would then be the responsibility of the adjudicator, in case of a dispute arising from such contract, to rule on the function and importance of international law. This is how arbitral practice has played a major role, by giving international law an increasing importance in the settlement of contractual disputes.

In cases of an express choice of law by the contracting parties

The freedom of the arbitrators. Even if the parties may have included a choice of law provision in their contract, arbitral tribunals in charge of enforcing such contracts generally have a certain margin of appreciation. They have largely used this margin to make international law at least partly applicable to such contracts. This is why we can say that the freedom characterizing international arbitration has greatly encouraged the internationalization of State contracts.

Choosing domestic law. The most striking aspect of this trend in favour of the application of international law appears in cases where the contracting parties opted for the application of domestic law. In such a case, one could think that the arbitral tribunal would have no choice but to apply national law. This is not, however, the tendency that we have seen in arbitration case-law. Some arbitral tribunals have indeed accepted applying the domestic set of rules chosen by the parties, but subjecting that application to its compliance with international standards. Formally, domestic law then remains the only one to be applied. But international law is not totally absent, even if the basis of its application remains weak. Two reasons may however explain the partial application of international law even when the parties have chosen domestic law. 
1.072 International law as an integral part of domestic law. The first and the simplest way of including international law within the law which is applicable to the contract is to assume that domestic law includes international law, as is the case in most national legal systems. In that case, the arbitral tribunal may apply all the relevant international rules that have been included within the domestic legal order. And it can be assumed that the international rules on foreign investment are surely relevant regarding a contract with a foreign investor. As soon as such rules have been introduced in domestic law, they can be deemed applicable. Such a reasoning is fully convincing and is still used by contemporary arbitral tribunals. ${ }^{64}$ The application of international law could thus stem from the application of domestic law, provided that the latter includes a mechanism of recognition and application of international norms.

1.073 The underdevelopment of domestic law. International law can also be introduced to the applicable rules when the domestic norms chosen by the parties are incomplete or obscure. In such a case, there is a need for other rules to solve the dispute: these can be found in international law. This is exactly what happened in the Petroleum Development (Trucial Coast) Ltd. $v$. Sheikh of Abu Dhabi case in 1951. It was not really clear what rules were meant to be applied but, in any event, the tribunal refused to enforce the law of the host State because it would be 'fanciful to suggest that in this very primitive region there is any settled body of legal principles applicable to the construction of modern commercial instruments' ${ }^{65}$ The wording, of course, is a little embarrassing and echoes the obsolete character of Article 38 of the Statute of the ICJ referring to 'civilized nations'. However, beyond this remark, the position expressed by the tribunal is very eloquent and provides a basis for the application of international law. Leaving aside any judgment in terms of development or civilization, it may be that a domestic law system would not provide any rule covering a contract signed between the State and a foreign private company. In such a case, two different hypotheses must be considered. Either the domestic law of the host State is not sufficiently comprehensive and has legal loopholes, creating a need to use additional standards and thus justifying the application of international law; or the domestic law of the host State has its own standards, but these do not provide sufficient protection for foreign investors. This second hypothesis is less convincing as it is grounded on a subjective assessment: the arbitrators would indeed have the considerable power to get rid of internal law if they consider it to be insufficiently protective. This position was endorsed by the tribunal in ARAMCO v. Saudi

64 Inceysa Vallisoletana, SL v. Republic of El Salvador, No. ARB/03/26, 2 August 2006, para. 220.

65 International and Comparative Law Quarterly 1952, 247. 
Arabia. In that case, the tribunal ruled that the domestic law designated as applicable by the contract:

should, where necessary, be interpreted or supplemented by the general principles of law, the uses followed in the petroleum industry and the data of pure legal science, especially when certain private rights which must necessarily be recognized by the dealer, as soon as the concession of its substance, would not be assured in a way undoubted by the law in force in Saudi Arabia. ${ }^{66}$

However, these common principles stemming from this so-called 'pure legal science' could certainly be found other than in international law. The latter is nevertheless surely relevant, as a common law of the nations. In any event, such a ruling renders applicable a set of rules that had never been formally designated as such by the contracting parties. This has the effect of giving the contract a brand new dimension.

Choosing international law. The application of international law is much easier when it has been agreed upon by the contracting parties. In practice, a great number of contracts refer both to international and domestic law in terms of applicable law. When it is the case, the issue is not so much whether or not international law is applicable but rather how to articulate it with domestic rules. This is quite a complex issue to which we will come back later. ${ }^{67}$ However, it is clear that international law applies if the parties choose to include it to the norms governing their contract.

\section{In the absence of a choice of law}

The absence of choice. It is not uncommon to encounter contracts that contain no mention of the applicable law in the event of a dispute. These are, for the most part, relatively old examples, since parties are nowadays experienced and it is widely known that such a provision is a strong guarantee for the preservation of their respective rights. Yet, it may happen that parties fail to decide on this point. Such a case raises the question of the possibilities offered to the arbitrators.

The application of international law. Here again, we may observe a general trend towards the application of international law, absent any choice made by the contracting parties. This is only a general tendency, which is of course 
subject to exceptions. ${ }^{68}$ Indeed, absent any provision on applicable law, arbitrators have no possibility other than to apply the private international law rules on connecting factors. It usually leads to the application of a domestic set of rules which in most cases is the law of the host State, since it is the country where the contract is being enforced. Nevertheless, as we have seen earlier, even the application of private international law principles may leave room for international law. For example, in the case of Sapphire v. National Iranian Oil Co. in 1963, the contract was silent on the question of applicable law. The tribunal considered that this silence revealed an absence of agreement between the parties as to the application of Iranian law, which therefore could not be applied. It added that the contract included a reference to the principles of good faith, which the arbitral tribunal interpreted as a reference to the general principles of law, within the meaning of Article 38 of the Statute of the ICJ. This applicability of international law was further strengthened by the subjectmatter of the contract which had to be qualified as 'quasi-international, escaping the sovereignty of particular legislators' ${ }^{69} \mathrm{We}$ can see that here again the absence of choice was interpreted in favor of international law.

1.077 An inherently international dimension. We could consider that State contracts are international instruments by nature, if we take into account their subject-matter and their parties. We could even draw an analogy with French public law (where the subject-matter of the contract may be sufficient to qualify it as administrative), ${ }^{70}$ by considering that a contract between a foreign investor and a State for the realization of a large-scale operation involving large sums of money is, by its very purpose, an international contract thus subject to international law. In a State contract, then, there is an intrinsically international dimension, given the very nature of the agreement. This does not mean, however, that all contracts signed between a private person and a foreign State should be subject to international law. But, in the event that the very purpose of this contract is the realization of an important operation for the State and is a support to its sovereign activity or its public service - mining, construction of a transport infrastructure, management of a distribution network of water or electricity - resorting to international law could be justified. Thus, as in an administrative contract, the subject-matter would justify that, by nature, the relationship has to be governed by international law.

68 For example in Soabi v. Senegal, No. ARB/82/1, 25 February 1988, JDI 1990, 193, the contract did not include any provision on applicable law. The tribunal therefore decided that, on the basis of the subject-matter of the agreement, only domestic law should be applied.

69 Sapphire International Petroleum Ltd. v. National Iranian Oil Company, 15 March 1963, Annuaire Suisse de droit international, 1962, 287.

70 See, in French, P. L. Frier and J. Petit, Précis de droit administratif, Montchrestien, 6th edn (2010), pp. 351 et seq. In English, L. Brown and J. Bell, French Administrative Law, Clarendon Press (1998), pp. 202 et seq. 
2. Identifying which international law norms are applicable to State contracts: a general overview

The legal issue. A State contract has been identified thus far as a contract 1.078 signed between a private party and a foreign State, subject to international law. Yet, the exact meaning and content of such law remains unclear, in this particular context. We will here only focus on a general approach, as the main object of this book is precisely to identify the content of the international norms that are applicable to investment operations. Yet, the problem will be addressed very briefly here, only in the context of contracts.

Private persons and public international law. It is common ground that 1.079 nothing prevents the application of international law to private persons. The PCIJ has already recognized that a treaty may directly create individual rights or obligations as long as this stems from its subject-matter or from the will of the parties. ${ }^{71}$ Individuals indeed hold rights in international law (human rights law), but they also have obligations through international criminal law. Therefore, there is no reason to object to the application of international law to an agreement concluded between a State and a foreign individual or company.

The relevance of lex mercatoria. The next question which arises is that of the existence, or not, of a 'transnational' law, which would be specific to contracts signed between States and foreign private persons. It would be a set of rules situated somewhere between public international law and domestic law. This set of rules has been identified as 'lex mercatoria' and was the object of much discussion some years ago. ${ }^{72}$ The main problem with it is not so much its existence but its applicability to State contracts. The lex mercatoria is indeed, as its name suggests, a set of principles born from the practice of 'merchants', that is to say rules applicable to purely commercial transactions including sale, supply or distribution. There are therefore instruments of which the object is not the same as that of State contracts. The main argument against the application of the lex mercatoria to State contracts - provided that its existence is established - is its inadequacy: like the administrative contract, the State contract is an intrinsically unbalanced instrument, since the State retains unilateral power in any case. The use of such power should be kept in check. This can be done in international law, for instance, by requiring the State to

71 Jurisdiction of the Courts of Danzig, Advisory Opinion, 3 March 1928, Series B, No. 15, p. 17.

72 See on this concept B. Goldman, "Frontières du droit et "lex mercatoria", Archives de philosophie du droit (1964), p. 177; C. M. Schmitthof, 'The law of international trade, its growth, formulation and operation: sources of the law of international trade', in C. M. Schmitthof (ed.), The Sources of the Law of International Trade, Praeger (ed.) (1964), p. 3. 
compensate the contracting parties in case of damage caused by the exercise of this power. But the rules that are applicable to a commercial relationship between a buyer and a seller cannot be fully transposed to a contract signed between a State and a foreign investor who came to the territory of the latter, in some cases, to assume a public service mission such as the distribution of drinking water or waste management. Thus, the very nature of the activity governed by State contracts seems to be an obstacle to the application of lex mercatoria principles.

1.081 Relevant principles of international law. In the light of the above, it must be admitted that international law by itself is applicable to State contracts. In reality, this debate seems a little outdated today: there was a time when the mere existence of international rules applicable to the relations between foreign investors and States could be questioned. But with the proliferation of investment protection treaties, this existence is no longer open to controversy. Today, these rules are undoubtedly reinforced by customary principles and general principles of law as per the definition set in Article 38 of the Statute of the ICJ. General rules such as good faith, the obligation of adequate compensation in the event of a breach of contract or the force majeure exception can be invoked and applied to a State contract without a doubt as to whether they are international norms.

1.082 A decline of State contracts? All the issues we have mentioned so far regarding the norms applicable to State contracts are still relevant today, but they should be addressed in an up-to-date legal context. Even though State contracts have not disappeared completely, they have lost some importance as a result of the emergence of international investment law. We can even say that they tend to be absorbed by this set of rules, which actually comprises among the most relevant norms applicable to this type of contract. We will now elaborate on this matter.

\section{BILATERAL INVESTMENT TREATIES AND THE BIRTH AND RISE OF INTERNATIONAL INVESTMENT LAW}

1.083 Simultaneous development. It is important to stress that the different evolutions described in this first chapter have not succeeded chronologically. The internationalization of State contracts and the development of international arbitration were actually parallel and mutually influenced each other. The same applies to the development of investment treaties, even if all three phenomena eventually merged into one in the early 1990 s. 


\section{The emergence and development of investment protection treaties}

The context of the emergence. It is always difficult, when it comes to history, to determine which event is a cause or a consequence of another when such events are closely interrelated. This is exactly the case with State contracts and investment protection treaties, except that we are certain on one point: investment treaties first appeared in a context that was very different from that of today. At the time when the first investment treaties were signed, ICSID did not exist and State contracts were barely defined as such. It is therefore almost impossible to determine whether investment treaties supported the development of State contracts, or if the emergence of State contracts created the need for investment treaties. In any event, both phenomena played a major part in the development of international investment law.

The appearance of BITs. The first bilateral investment protection and promotion treaty (BIT) was concluded in 1959, when Germany and Pakistan signed a treaty in which they committed to guarantee a certain level of protection to their respective investors. There is no doubt that some instruments including provisions on the protection of foreign investors already existed at that time, even if that was not their main purpose. But it is true that the 1959 Treaty is peculiar in that its exclusive purpose was the protection of investors who were nationals of the other State party, a feature which was quite innovative at that time. As we can see, the first BIT was signed at the time when arbitral tribunals settled the first major investor-State disputes. These first cases were also the starting point of the internationalization of the relationship between States and investors. It is no coincidence: submitting a relationship to international law is one thing, identifying relevant rules of international law is another. The first BITs were thus signed in order to define which international law rules were applicable to State contracts. We should also point out that States were quite concerned about this phenomenon of internationalization being developed by arbitral awards. They were afraid of losing their control over the rules which were applicable to the contracts they had signed with foreign investors. Indeed, as we have seen, States did not initiate this trend towards internationalization: it started with the interpretation of contractual provisions by arbitral tribunals. Negotiating BITs was thus a way for States of getting some control back by defining themselves the international norms that would be applicable to State contracts.

The evolution of BITs. Despite their importance, BITs did not develop very quickly at first. Their growth in the early years was modest but steady, with a few additional treaties being signed every year. Their growth only became exponential in the 1990s, leading to nearly 3,000 treaties in force around the 
world today. We could argue that this network lacks consistency today, since its development was spontaneous and was not structured or controlled by any central authority. However, this assumption is wrong for several reasons.

1.087 Common roots. First, all BITs have several common roots, which explains that despite their bilateral nature - which could entail that they are all different - their content is quite similar. Two main sources indeed inspired the negotiators of BITs: on the one hand, treaties of friendship, commerce and navigation started developing in the nineteenth century and were themselves quite similar. On the other hand, several international organizations or institutions had published draft models, without any legal value per se, which largely inspired the drafters of BITs. One may think in particular of the Draft Convention on the Protection of Foreign Property that was published by the Organization for Economic Cooperation and Development in the late 1960s. ${ }^{73}$ This twofold common root explains why BITs are quite similar nowadays.

1.088 Geographic universality. Second, resorting to a BIT is not a trend or a practice which is limited to a group of States or to a specific region. Virtually all States have now concluded at least one BIT, which suggests that this practice is universal from a geographical point of view. In addition, treaties are no longer only signed between northern and southern countries, as was the case at first, since investors mainly originated from Western countries and invested in developing ones. Treaties between countries of the South or between countries of the North are quite frequent today, and the main flows of investments are made between countries of an equivalent level of development. ${ }^{74}$ Some States have signed several of them, as most developed countries have: to take only one example, France is now bound by more than 100 bilateral investment protection treaties.

1.089 National Models System. Finally, it must be noted that most of the States that play a key role in international investment, whether they are large suppliers of investors or host a large number of investments, have all drafted treaty models. They would use these same models with all parties, introducing the necessary amendments. By adopting a draft model convention, these States do not take any commitment (another State can refuse the drafting and ask for a series of modifications which can lead to a radical transformation of the text) but it gives them a basis for negotiation. That explains why most of

74 UNCTAD, International Investment Rule-Making: Stocktaking, Challenges and the Way Forward, Geneva, United Nations Publications (2008), p. 110. 
the BITs signed by one State are usually quite similar, which is another element in support of consistency.

Multilateralization? A more recent trend has emerged in conventional practice, which is also an element advocating for the existence of a consistent set of rules. Several States have indeed signed multilateral instruments including rules on investment protection. Such instruments are in general limited as to their geographical scope, like the NAFTA to which only the US, Canada and Mexico are party and that includes a chapter 11 on investment protection. These treaties may also be limited in their material scope, such as the Energy Charter Treaty, which deals only with investments in the energy sector. Such treaties contain rules that are very similar to those of the BITs and can certainly be mentioned in the context of this major normative development. The example of European Union (EU) law is particularly relevant in this respect: although its purpose seems at first glance relatively remote, we will see that many European rules can in fact be considered as investment protection rules. Besides, the EU has recently negotiated large-scale agreements including investment protection provisions, such as the Comprehensive Economic and Trade Agreement with Canada, signed on October 30, 2016. Generally speaking, one can notice a global trend in upscaling investment agreements ${ }^{75}$ so that the future of investment treaties might be multilateral rather than bilateral. ${ }^{76}$

The content of BITs. We may say that the content of BITs is actually the object of this textbook. It is therefore not necessary to dwell on it here, evoking the main provisions that are systematically present in BITs should be sufficient. The treaties comprise first a provision dedicated to definition, to identify in particular the notion of investment, which still raises significant issues today. BITs also include provisions about the substantive protection of foreign investors: a general guarantee of fair and equitable treatment, protection against direct or indirect expropriation (by making it subject to the payment of adequate compensation), most-favoured-nation treatment, guarantee of free transfer of funds, etc. Finally, an arbitration clause offers the investor access to an arbitral tribunal, generally with a reference to the rules of ICSID or to any other arbitration institution. Even if some details may vary, the great majority of BITs are drafted in the same way, and include all the abovementioned provisions.

76 This is also due to a contestation movement against BIT, see infra, para. 1.102. 
2. The AAPL Award and the emergence of contemporary investment law

1.092 BITs and State Contracts. Everything that we have described so far was part of a specific legal context, that of State contracts. The development of international rules through the development of investment protection treaties indeed aimed, at first, to determine the content of the (international) law rules applicable to State contracts. In a nutshell, it could be said that State contracts were progressively submitted to international law but that the content of the international rules that were applicable to them was not clear. The purpose of BITs was thus to define such content and to apply it to State contracts. Both instruments were therefore closely related, but things were about to change radically.

\section{(a) A new consent to arbitration}

1.093 Needing State contracts. In the legal context we have described so far, a BIT can only be useful if it is based on a contract, and this is the reason why these treaties were initially described as 'umbrella treaties': they are instruments aiming at 'covering' contractual relations since they merely provide rules that are applicable to State contracts. Accordingly, resorting to international arbitration if the BIT is breached was only possible for the investor if it had signed a contract with the host State, in which the latter gave its consent to arbitration. That is the point on which the $A A P L$ award brought a significant change.

1.094 Background of the case. The facts of the $A A P L$ case were not very complex. ${ }^{77}$ AAPL was a British company with its seat in Hong Kong at a time when Hong Kong was still part of the UK. AAPL managed a shrimp factory in Sri Lanka where violent civil unrest took place in the late 1980s. One day, a conflict occurred between the Sri Lankan army and some rebel groups in the area where the factory was located, destroying it almost completely. AAPL thus sought reparation for its loss, but the legal issue was that it had not signed any contract with the State of Sri Lanka. The only legal relationship that existed was between AAPL and private Sri Lankan companies. In the absence of any contract with the State, therefore, the company could not sue the State before an arbitral tribunal. Yet, the company decided to act on the basis of the arbitration clause of the BIT that had been signed between the UK and Sri Lanka, to which, as a private person, it was not a party. It was a gamble, but it turned out to be successful. 
A new reading. The arbitration clause of the treaty provided that ' $[\mathrm{e}] \mathrm{ach}$ Contracting Party hereby consents to submit to the International Centre for Settlement of Investment Disputes [...] any legal dispute arising between the Contracting Party and a national or company of the other Contracting Party concerning an investment of the latter in the territory of the former'. The tribunal considered that such provision expressed the consent of the State to arbitration with foreign investors but also that it recognized the right, for any such investor, to go before an arbitral tribunal on the basis of the treaty. This recognition of a right of foreign investors is the main and tremendous innovation brought by this case. Even if such a right is not explicitly recognized in the provision, it is not excluded either: the treaty provides for the jurisdiction of arbitral tribunals over disputes arising between a private person and a State, but without openly saying who holds the right to go before a judicial authority. For the tribunal, this stipulation should be analysed as a 'standing offer of arbitration' made by the State. It is up to the investor to express its own consent by filing an arbitration claim. Therefore, the consent of both parties is accounted for and they can express it in a deferred and non-simultaneous manner.

The emergence of an arbitration 'without a legal connection'. Even if this reasoning seems somewhat artificial, the basic legal principles and rules are being upheld here. Both parties have indeed expressed their consent, and their will underpins the jurisdiction of the arbitral tribunal. Some have stressed the somewhat forced dimension of State consent, but never claiming a return to the previous situation. J. Paulsson thus talks about an arbitration "without privity'78 and W. Ben Hamida uses the expression of 'unilateral arbitration'.79 But in any event, the question of consent no longer arises today: it is now widely accepted, since the AAPL award, that by signing a BIT with an arbitration clause, a State consents to recognize a right to resort to arbitration to investors who are nationals of the other State Party to the treaty.

\section{(b) The development of international investment law since 1990}

The consequences of the $A A P L$ case. The interpretation of State consent in

$\mathrm{BIT}$ s is no longer questioned but the consequences of such a recognition are tremendous. The AAPL award actually modified the entire structure of international investment law. It could be said, to a certain extent, that 'modern' investment law was born in 1990 with this major decision.

78 J. Paulsson, 'Arbitration without privity', 2 ICSID Review - FILJ 232 (1995).

79 W. Ben Hamida, L'arbitrage transnational unilatéral - réflexions sur une procédure réservée à l'initiative d’une personne privée contre une personne publique, $\mathrm{PhD}$ Thesis, Univ. Paris 2, 2003. 
1.098 Expressing consent in a statute. A BIT is not the only instrument in which a State may consent to the jurisdiction of an arbitral tribunal. Two years before $A A P L$, another arbitral tribunal had indeed accepted that the consent of the State may be expressed in a national statute. Such a bill can then be analysed as a permanent offer of arbitration. ${ }^{80}$ This decision is almost as important as the $A A P L$ case because both of them establish a possibility for foreign investors to go before an arbitral tribunal against a State, either on the basis of a treaty or a domestic bill. This twofold solution explains why international investment law grew exponentially after 1990 .

1.099 The exponential growth of BITs. The main effect of the $A A P L$ case was to give a new dimension to BITs. Indeed, recognizing that the mere existence of a BIT means a right to resort to arbitration, in addition to the substantive protection included in the provisions of the treaty, considerably strengthens the value of such treaties. That explains why, from the beginning of the 1990s, many BITs were signed. There are more than 3,000 treaties in force today, and they provide the main basis of contemporary investment law. Therefore, as we have seen, investment law did not appear with the $A A P L$ award but it can be assumed that this case gave it its contemporary form, of which the main features are the following.

1.100 The importance of case-law. First, contemporary investment law is largely based on arbitration case-law. The number of awards issued each year continues to grow, and litigation becomes increasingly complex. The procedural dimension of investment law has become of primary importance and arbitral tribunals have developed very rich and stimulating - though sometimes questionable - interpretations of substantive protection provisions of BITs. Due to its own features, ICSID has become the most important institution for the settlement of investment disputes, in such a way that today, the ICSID and investment law are described as being almost the same thing. ${ }^{81}$

1.101 Diversification. Investment operations have diversified considerably. Indeed, the economic sectors in which the first rules had developed (oil, natural resources mainly, but also transport infrastructure) represent only a part of the operations governed by international investment law today. The growth of investment in the sector of various public services (water distribution, electricity production and distribution, management of communication networks, waste management, etc.) or in the service economy (insurance, banks, hotels,

80 Southern Pacific Properties (SPP) v. Egypt, April 14, 1988, JDI 1994, 220.

81 See, e.g., for a vision of investment law through ICSID, M. Kinnear, G. R. Fischer, J. Mínguez Almeida, L. Fernanda Torres and M. Uran Bidegain (eds), Building International Investment Law. The First 50 Years of ICSID, Wolters Kluwer (2016). 
etc.) has been considerable. Contemporary investment law is relevant for all types of transactions, whatever their nature and scope: as a part of international economic law, it relates to the economy as a whole.

Recent challenge. Finally, BITs and what they represent have been called into question in recent years. While this is unlikely to represent a risk for the future of the discipline, it will undoubtedly lead to a number of changes in coming years. This challenge is actually twofold: on the one hand, some States are starting to contest the unilateral character of investment law and then start to reconsider their commitment in ICSID: the denunciation of the Washington Convention by Bolivia (2007), Ecuador (2009) and then Venezuela (2012) is certainly indicative of a hostility towards the existing system. The fact that Brazil never ratified the Washington Convention or any BIT is also revealing. On the other hand, in a less ideological way, it must be emphasized that investment law does not lie exclusively in BITs or in ICSID tribunals. The vast majority of transactions take place without litigation, or may give rise to domestic procedures. We should highlight that international arbitration is first and foremost a last recourse, which will not be used by all the investors who experience troubles with States. It is therefore essential to understand that the international investment law described here is only a small part of the economic reality. 